\title{
Lethal and sublethal effects of ten insecticides, used in date palm production in Saudi Arabia, on the parasitoid Trichogramma cacoeciae
}

\author{
M. Jamal Hajjar* and M. Al-Masoud
}

Summary Lethal and sublethal effects of ten insecticides commonly used in date palm production in Saudi Arabia were assessed in the laboratory against adults of Trichogramma cacoeciae, an important egg parasitoid of the dried fruit moth Ephestia calidella. Bioassays were conducted according to the standard protocol of the International Organization for Biological Control IOBC/WPRS/Working Group 'Pesticides and Beneficial Organisms'. Our results showed that cypermethrin, deltamethrin, malathion, phenthoate, methomyl, and carbosulfan were moderately harmful (IOBC Class 3) to the parasitoid. The botanical insecticides azadirachtin and matrine were moderately harmful (IOBC Class 3 ) and slightly harmful (IOBC Class 2), respectively. The insect growth regulator pyriproxyfen was slightly harmful, whereas bistrifluron was harmless (IOBC Class 1). Regarding sublethal effects, the parasitism ratios compared to control were reduced by pyriproxyfen and azadirachtin to $49.0 \%$ and $58.0 \%$, respectively; hence they are classified as slightly harmful insecticides (IOBC Class 2). Bistrifluron and matrine were harmless (IOBC Class 1) as parasitism ratios were reduced by $9.2 \%$ and $27.6 \%$, respectively. Longevity of adults exposed to bistrifluron and matrine (3.6 and 3.3 days, respectively) and to pyriproxyfen and azadirachtin (1.7 and 1.3 days, respectively) was significantly lower than that in control (4.67 days). In semi-field tests, residues of most insecticides on leaves of tomato, a common host plant of lepidopteran pests parasitized by T. cacoeciae, were considered moderately harmful to harmful based on parasitoid mortality at $24 \mathrm{~h}$ post-treatment whereas they were slightly harmful at 7 and 14 days post-treatment.

Additional keywords: longevity, mortality, parasitism, sublethal effects, Trichogramma cacoeciae, viability

\section{Introduction}

Species of Trichogramma (Hymenoptera: Trichogrammatidae) are important parasitoids in natural and agricultural ecosystems and act as effective biocontrol agents of lepidopteran pests in important crops such as tomato, soybean and cruciferous plants (Godfray, 1994; Beserra and Parra 1994; Moezipour et al., 2008; Polaszek, 2010).

The dried fruit moth Ephestia calidella (Guenée) (Pyralidae) is a pest of economic importance on date palm in Saudi Arabia, attacking dates during harvest, storage and packinghouse processing (El-Shafie et al., 2017). Development of the pest and its dam-

College of Agricultural and Food Sciences, King Faisal University, Saudi Arabia.

* Corresponding author: jamalnoura@yahoo.com aging impacts on date palms are restricted by the use of the parasitoid Trichogramma cacoeciae Marchal (Rubeai et al., 2003; El-Shafie et al., 2017), which is commercially available and the most commonly used natural enemy in biological control programs (Hassan, 1993; Hassan et al., 2000).

Nevertheless, application of insecticides for the control of date palm pests cannot be excluded and sustainable use is foreseen in the frame of an Integrated Pest Management plan. Therefore, there is an urgent need to assess and quantify the risks of pesticides against natural enemies of date palm pests in order to minimize any adverse effects. Pesticides may cause lethal effects to nontarget organisms in addition to sub-lethal behavioral and development effects, such as changes in rates of parasitism, longevity, sex ratio, and adult emergence (Desneux et al., 2007; Firake and Khan, 2010; Firake et al., 
2012; Blibech et al., 2015).

Toxicity of different classes of insecticides to Trichogramma spp. vary. Synthetic pyrethyroid insecticides appear to be the most harmful class (Youssef et al., 2004; Abdulhay and Rathi, 2014; Sohrabi and Amini, 2015; Thubru et al., 2016); Furthermore, the effect of deltamethrin on pupae of Trichogramma oleae (Voegele and Poitale), T. cacoeciae, and T. bourarachae Pintureau and Babault persisted for 30 days following exposure (Blibech et al., 2015).

The neonicotinoid insecticide acetamiprid was harmful as regards adult emergence and rates of parasitism of Trichogramma evanescens Westwood (Jiu-Sheng et al., 2010). Thiacloprid was harmful to T. cacaoeciae adults but harmless to larvae and pupae (Schuld and Schmuck, 2000).

Organophosphate insecticides have been shown to be harmful to eggs of $T$. evanescens and Trichogramma platneri Nagarkatti (Jiu-Sheng et al., 2010; Brunner et al., 2001) and moderately harmful to T. cacoeciae (Youssef et al., 2004).

Insect growth regulators and insect growth inhibitors (fenoxycarb, diflubenzuron and lufenuron) have been reported not to be harmful to adults, pupae or eggs of T. cacoeciae (Hassan et al., 1998; Brunner et al., 2001; Abaar et al., 2010). Consoli et al. (2001) found that lufenoron and triflumuron did not affect parasitism efficiency in T. galloi Zucchi, although they were harmful when applied to larvae and caused $100 \%$ death rate in adults when applied to eggs.

Abdelgader and Hassan (2012) reported that azadirachtin was harmful to T. cacoeciae adults, which were exposed to residues on glass plates and slightly to moderately harmful regarding adult emergence when applied to parasitized host eggs at different time intervals.

Herein, we studied lethal, sublethal and persistence effects of ten insecticides, which are commonly used in date palm production in Saudi Arabia, on T. cacoeciae. Adults of the parasitoid were exposed to dry residues of the highest recommended rates of the test insecticides thus at very high risk (Hassan et al., 2000), likely resulting in the greatest degree of harm. The outcome of lethal/sublethal effects together with the results on the insecticide persistence will contribute to the selection of insecticides that pose lower risk to the parasitoid and to determine the conditions of safe use in IPM programs in date palm plantations (Grutzmacher et al., 2004).

\section{Material and Methods}

\section{Trichogramma cacoeciae cultures}

Trichogramma cacoeciae was selected among Trichogramma spp. for the bioassays as it is easy to rear and handle in the laboratory (Hassan 1998). Trichogramma cacoeciae was obtained from a colony maintained at the Excellence Research Center for palms and dates at the King Faisal University. The colony originated from parasitized Lepidopteran eggs on leaves of cruciferous, tomato and other Solanaceae plants cultivated at Al-Hassa fields, Eastern province of Saudi Arabia. Adults of T. cacoeciae were reared on eggs of Ephestia cautella (Walker) (Lepidoptera: Pyralidae) (Suh et al., 2000), in an insect growth chamber maintained at $23 \pm 2{ }^{\circ} \mathrm{C}$ and $75 \pm 5 \%$ relative humidity $(\mathrm{RH})$ with a 16:8 L:D cycle.

\section{Insecticides}

Lethal and sublethal effects on T. cacoeciae were assessed for 10 commonly used and commercially available insecticides in Saudi Arabia against pests of date palms. The insecticides are presented in Table 1 and contain active substances which belong to different chemical groups (pyrethroids, organophosphates, carbamates, Insect Growth Regulators and plant extracts).

\section{Lethal effects of insecticides}

Lethal effects of insecticides were assessed on T. cacoeaciae adults after exposure to dry residues on glass plates using the highest recommended application rates (Hassan et al., 2000). Glass tubes $(2.5 \times 20 \mathrm{~cm})$ were treated by adding $5 \mathrm{ml}$ of an aqueous insecticide solution which covered the inner surface; the tubes were then emptied and left to 
Table 1. List of insecticides used in the study.

\begin{tabular}{|c|c|c|c|}
\hline Insecticides & Class & $\begin{array}{c}\text { Recommended } \\
\text { application rate } \\
(\mathrm{ml} / \mathrm{L})\end{array}$ & Manufacturing company \\
\hline Cypermethrin (Hi power10\% EC) & Pyrethroid & 0.50 & Sulphur mills limited- India \\
\hline Deltamethrin (Flotron 2.5\% EC) & Pyrethroid & 0.35 & Sulphur mills limited-India \\
\hline Malathion (Sulmathion 57\% EC) & Organic phosphorus & 0.75 & Sulphur mills limited- India \\
\hline Phenthoate (Peston 50\% EC) & Organic phosphorus & 0.80 & Astrachem - Saudi Arabia \\
\hline Methomyl (Metho900 SP) & Carbamate & 0.20 & BASF Corporation - Germany \\
\hline Carbosulfan (Marshal 25\% WP) & Carbamate & 0.50 & Astrachem - Saudi Arabia \\
\hline Bistrifluron (Hanaro 10\% EC) & $(\mathrm{IGR})$ & 1.00 & Astrachem - Saudi Arabia \\
\hline Pyriproxyfen (Muligan 10\% EC) & $(I G R)$ & 0.75 & Parabolan- Spain \\
\hline Matrine (Kingbo 0.6\% EC) & Plant Extract & 2.00 & Beijing Kingbo Biotech- China \\
\hline Azadirachtin (Amen 1.0\% EC) & Plant Extract & 2.50 & Ecopheosides - India \\
\hline
\end{tabular}

dry for $3 \mathrm{~h}$. Control tubes were treated with distilled water. Five replicates of glass tubes per insecticide treatment were used. Twenty adults of $T$. cacoeciae, which were 24 hours old, were transferred to each treated tube after drying, using a fine feather. The tubes were then sealed using cotton previously dipped in $50 \%$ honey solution and were kept in an incubator at $26 \pm 2^{\circ} \mathrm{C}, \mathrm{RH} 75 \pm 5 \% \mathrm{RH}$ and $16: 8$ $\mathrm{L}: \mathrm{D}$ cycle. After $24 \mathrm{~h}$ of exposure to the dry insecticide residues, the effect on adult mortality was recorded. The classification system of the International Organization for Biological Control (IOBC) was used for the classification of the insecticide toxicity as: harmless (<30\% mortality, Class 1); slightly harmful (30$79 \%$ mortality, Class 2); moderately harmful (80-99\% mortality, Class 3); or harmful (>99\% mortality) (Hassan et al., 2000).

\section{Sublethal effect on parasitism}

Sublethal effect on parasitism were assessed on adult females of $T$. cacoeciae, which had survived the $24 \mathrm{~h}$ exposure to insecticide residues (bistrifluron 10\% EC; pyriproxyfen $10 \%$ EC; matrine $0.6 \%$ EC; azadirachtin $1.0 \% \mathrm{EC}$, and control). Females were placed in glass tubes $(2.5 \times 20 \mathrm{~cm}), 6$ individuals per tube, along with $100 \pm 10$ eggs of $E$. cautella, which were glued on cardboard tape $\left(1 \mathrm{~cm}^{2}\right)$. The females were provided with food through a cotton wool, which had been dipped in 50\% honey solution, and served also as a closure of the tubes.
Five tubes (replicates) were used per insecticide treatment and the control and were kept at $26 \pm 2^{\circ} \mathrm{C}, \mathrm{RH} 75 \pm 5 \% \mathrm{RH}$ at a 16:8 L:D cycle. The eggs of $E$. cautella were removed from the glass tubes after $24 \mathrm{~h}$ exposure to the parasitoids and placed in labeled $\mathrm{Pe}$ tri dishes corresponding to the replicates, in the incubator. After 9 days of incubation, the number of parasitized eggs was counted and parasitism ratios of the insecticide treatments were compared with the control. The IOBC classification (Hassan et al., 2000) was used for the classification of insecticide toxicity and the data were corrected using the Abbott's formula (Abbott 1925).

\section{Sublethal effects on parasitoid longevity}

Sublethal effect of insecticides on parasitoid longevity was also assessed on adult females which survived $24 \mathrm{~h}$ exposure to the insecticide treatments. Female individuals were placed individually in clean glass tubes sealed with cotton wool, which had been dipped in $50 \%$ honey solution, and were incubated as described before. Five tubes (replicates) per insecticide treatment and the control were used. Longevity of the parasitoid as number of days until death was recorded.

\section{Persistence effects on parasitoid mortality}

The persistence effect of insecticides, ap- 
plied to tomato leaves, on T. cacoeciae adults was assessed. The experiment was conducted on tomato leaves because it is a common host for lepidopteran insects parasitized by $T$. cacoeciae. For this purpose, 75 tomato seedlings of the local cultivar Alhassawi were transplanted in five replicate plots, each measuring $2 \times 3 \mathrm{~m}$. Plants were grown in a mixture of peat moss ( $75 \%$ by vol.), native fine sand, perlite and vermiculite.

Each insecticide was applied to plants in four replicate plots, while the control (water) was applied to the fifth plot. Following treatment with insecticide or water, the plants were left to dry for three hours. Five tomato leaves, measuring 5-6 cm long, were randomly collected from the upper third of the plant in each plot of each insecticide treatment. Each set of five leaves, representing one replicate per treatment, was placed in a separate bag and transferred to the laboratory. Leaves were cut into $1 \mathrm{~cm}^{2}$ pieces and placed in a test tube $(5 \times 1.5 \mathrm{~cm})$ along with $20 \mathrm{x}$ one day old adults of T. cacoeciae (Suh et al., 2000). The tubes were then sealed with cotton wool and kept in an incubator for 24 h, before mortality was recorded at 1, 2, 3, 7,
14 days post-treatment. Mortality ratio data were corrected using the Abbott's formula (Abbott, 1925).

\section{Statistical analysis}

The experiment was designed as a randomized complete block design using five replicates per treatment in addition to the control. Corrected percent mortality was calculated (Abbott 1925) and data were analyzed using Analysis of Variance (ANOVA). Separation of the means was conducted using the Fisher's protected Least Significant Difference test (PLSD), $(P<0.05)$ (Steel et al., 1997). The analyses were performed using SPSS 12.0 Windows (SPSS Inc., 2003).

\section{Results and Discussion}

\section{Lethal Effects}

Survival and corrected mortality of adult females of $T$. cacoeciae after $24 \mathrm{~h}$ exposure to dry insecticide residues differed among the insecticides (Table 2). Cypermethrin, deltamethrin, malathion, phenthoate, methomyl and carbosulfan, were moderately harmful

Table 2. Survival and corrected mortality of adult females of the egg parasitoid Trichogramma cacoeciae, when exposed to dry residues of insecticides on glass surfaces treated at the recommended application rates.

\begin{tabular}{|c|c|c|c|c|}
\hline \multicolumn{2}{|c|}{ Treatment } & \multirow{2}{*}{ Adult survival } & \multirow{2}{*}{$\begin{array}{c}\text { Corrected } \\
\text { mortality } \\
\text { (E\%) }\end{array}$} & \multirow{2}{*}{ IOBC Classification } \\
\hline Insecticide & Class & & & \\
\hline $\begin{array}{l}\text { Cypermethrin (Hi power) } \\
\text { Deltamethrin (Flotron 2.5\%) }\end{array}$ & \multirow[b]{2}{*}{ Organophosphate } & $\begin{array}{l}2.00 \pm 0.77 \mathrm{gh} \\
4.33 \pm 0.26 \mathrm{efg}\end{array}$ & $\begin{array}{l}98.00 \\
95.67\end{array}$ & $\begin{array}{l}3 \\
3\end{array}$ \\
\hline $\begin{array}{l}\text { Malathion (Sulmathion 57\%) } \\
\text { Phenthoate (Peston 50\%) }\end{array}$ & & $\begin{array}{c}1.00 \pm 0.45 \mathrm{~h} \\
3.33 \pm 0.26 \mathrm{fgh}\end{array}$ & $\begin{array}{l}99.00 \\
96.67\end{array}$ & $\begin{array}{l}3 \\
3\end{array}$ \\
\hline $\begin{array}{l}\text { Methomyl (Metho900) } \\
\text { Carbosulfan (Marshal 25\%) }\end{array}$ & Carbamate & $\begin{array}{l}1.00 \pm 0.45 \mathrm{~h} \\
5.00 \pm 0.45 \mathrm{ef}\end{array}$ & $\begin{array}{l}99.00 \\
95.00\end{array}$ & $\begin{array}{l}3 \\
3\end{array}$ \\
\hline $\begin{array}{l}\text { Bistrifluron (Hanaro 10\%) } \\
\text { Pyriproxyfen (Muligan 10\%) }\end{array}$ & \multirow{3}{*}{ Plant Extract } & $\begin{array}{l}92.67 \pm 0.7 \mathrm{~b} \\
40.33 \pm 0.68 \mathrm{~d}\end{array}$ & $\begin{array}{l}7.33 \\
59.76\end{array}$ & $\begin{array}{l}1 \\
2\end{array}$ \\
\hline $\begin{array}{l}\text { Matrine (Kingbo 0.6\%) } \\
\text { Azadirachtin (Amen 1.0\%) }\end{array}$ & & $\begin{array}{l}50.00 \pm 0.89 c \\
6.67 \pm 1.37 e\end{array}$ & $\begin{array}{l}50.00 \\
93.33\end{array}$ & $\begin{array}{l}2 \\
3\end{array}$ \\
\hline Control & & $100.0 \pm 0.00 \mathrm{a}$ & & - \\
\hline $\operatorname{LSD}(P>0.05)=28.639$ & & & & \\
\hline $\mathrm{F}$ value $=0.041$ & & & & \\
\hline
\end{tabular}

All values are means of 5 replicates \pm SE. Means in the same column followed by the same letter are not significantly different (Fisher's test, $\mathrm{P}>0.05)$. IOBC insecticide classification, where Class 1: harmless $(\mathrm{E}<30 \%)$; Class 2: slightly harmful $(30 \%<\mathrm{E}<79 \%)$; Class 3: moderately harmful $(80 \%<\mathrm{E}<99 \%)$; and Class 4: harmful $(\mathrm{E}>99 \%)$. 
(IOBC class 2) to the parasitoid T. cacoeciae, according to the IOBC classification system (Hassan et al., 2000). Similar moderate to high toxicities of organophosphorus and synthetic pyrethroid compounds to adults of $T$. Cacoeciae and other Trichogramma spp. have also been reported in other studies (Brunner et al., 2001, Youssef et al., 2004; Jiu-Sheng et al., 2010, Zhu et al., 2009; Abaar et al., 2011; Sohrabi and Amini, 2015; Thubru et al., 2016).

The plant extract azadirachtin (Amen $1.0 \%)$ was moderately toxic, supporting data from Thubru et al. (2016) on another egg parasitoid, Trichogramma brassicae (Bezdenko).

The insect growth regulator (IGR) pyriproxyfen (Muligan 10\%) and the plant extract matrine (Kingbo $0.6 \%$ ) are slightly harmful (IOBC class 3 ) to the parasitoid T. cacoeciae while the IGR bistrifluron is harmless (corrected mortality did not exceed 7.3\%; IOBC class 1 ).

\section{Sublethal effects}

Parasitism ratio of E. cautella eggs by female parasitoids of $T$. cacoeciae, which had survived $24 \mathrm{~h}$ exposure to dry insecticide residues, was significant lower compared to the control, while it differed among the tested insecticides (Table 3). Similarly, longevity of adult females of T. cacoeciae that survived initial $24 \mathrm{~h}$ exposure to the insecticide resi- dues was significantly lower than that of the control but there were variations in the effect among the insecticides (Table 3).

Based on parasitism ratios of $T$. cacoeciae on E. cautella, the IGRs pyriproxyfen and bistrifluron are classified as slightly harmful (IOBC class 2 ) and harmless (IOBC class 1 ) to T. cacoeciae, respectively. The plant extracts azadirachtin and matrine are classified as slightly harmful (IOBC class 2 ) and harmless (IOBC class 1 ) to the parasitoid, respectively. In terms of effect on longevity, the most harmful insecticides to the parasitoid were pyriproxyfen and azadirachtin (Table 3).

Regarding IGRs, Consoli et al. (1998) and Hassan et al. (1998) found that lufenuron was slightly harmful to T. cacoeciae. However, Abaar et al. (2010) reported that fenoxycarb, diflubenzuron, and lufenuron were not harmful to pupae or toxic to T. cacoeciae eggs and the low toxicity levels of IGR in $T$. cacoeciae larvae have been reflected in the high rates of adult emergence compared to the control.

Azadirachtin, although a botanical insecticide, was found to be moderately harmful to $T$. cacoeciae regarding mortality and slightly harmful regarding parasitism ratio. Our results are in conflict with those reported by Thubru et al. (2016), who found that surface contact toxicity of azadirachtin was

Table 3. Parasitism ratio of Trichogramma cacoeciae on eggs of Ephestia cautella and longevity of adult females of the parasitoid, which survived $24 \mathrm{~h}$ exposure to dry residues of insecticides on glass plates treated at the recommended application rates.

\begin{tabular}{|c|c|c|c|c|c|}
\hline \multicolumn{2}{|l|}{ Treatment } & \multirow{2}{*}{$\begin{array}{l}\% \text { hatching after } \\
\text { nine days } \pm \text { SE }\end{array}$} & \multirow{2}{*}{$\begin{array}{c}\text { Reduction } \\
\text { in parasitism } \\
\text { rate }(E \%)\end{array}$} & \multirow{2}{*}{$\begin{array}{c}\text { IOBC } \\
\text { Classification }\end{array}$} & \multirow{2}{*}{ Longevity (days) } \\
\hline Insecticide & Class & & & & \\
\hline $\begin{array}{l}\text { Bistrifluron (Hanaro 10\%) } \\
\text { Pyriproxyfen (Muligan 10\%) }\end{array}$ & IGR & $\begin{array}{l}83.80 \pm 4.40 b \\
47.13 \pm 4.21 d\end{array}$ & $\begin{array}{c}9.21 \\
48.98\end{array}$ & $\begin{array}{l}1 \\
2\end{array}$ & $\begin{array}{c}3.60 \pm 0.20 b \\
1.67 \pm 0.12 c\end{array}$ \\
\hline $\begin{array}{l}\text { Matrine (Kingbo 0.6\%) } \\
\text { Azadirachtin (Amen 1.0\%) } \\
\text { Control }\end{array}$ & $\begin{array}{l}\text { Plant } \\
\text { Extract }\end{array}$ & $\begin{array}{l}66.73 \pm 2.61 \mathrm{c} \\
40.93 \pm 3.52 \mathrm{e} \\
92.33 \pm 4.04 \mathrm{a}\end{array}$ & $\begin{array}{l}27.64 \\
57.95\end{array}$ & $\begin{array}{l}1 \\
2\end{array}$ & $\begin{array}{l}3.27 \pm 0.12 b \\
1.33 \pm 0.12 c \\
4.67 \pm 0.58 a\end{array}$ \\
\hline $\begin{array}{l}\operatorname{LSD}(P>0.05)=25.345 \\
F \text { value }=0.046\end{array}$ & & & & & $\begin{array}{l}\operatorname{LSD}(P>0.05)=1.622 \\
\operatorname{LSD}(P>0.05)=1.622\end{array}$ \\
\hline
\end{tabular}

All values are means of 5 replicates \pm SE. Means in the same column followed by the same letter are not significantly different (Fisher's test, $\mathrm{P}>0.05)$. IOBC insecticide classification, where Class 1: harmless (E < 30\%); Class 2: slightly harmful $(30 \%<\mathrm{E}<79 \%)$; Class 3: moderately harmful $(80 \%<\mathrm{E}<99 \%)$; and Class 4: harmful $(\mathrm{E}>99 \%)$. 
slightly harmful to adults of $T$. brassicae mortality, while it was harmful to parasitism ratio and longevity of the parasitoid. These differences may be due to differences in sensitivity to insecticides among Trichogramma species as well as the host species upon which the parasitoid species are reared (Brunner et al., 2001).

To summarize, the two IGRs (bistrifluron, pyriproxyfen) and the plant extract matrine were the least harmful insecticides to adults of $T$. cacoeciae in terms of lethal effect (mortality after $24 \mathrm{~h}$ exposure) as well as sublethal effects (parasitism ratio on E. cautella and parasitoid longevity). Bistrifluron and pyriproxyfen have been classified in the IOBC database as harmless to T. cacoeciae (IOBC, 2005). Our results support this classification for bistrifluron but not for pyriproxyfen, which was classified as slightly harmful. This difference in classification may be due to variability in sensitivity to pesticides among Trichogramma spp., caused by host rearing conditions e.g. size of host egg that affects the growth and development of parasitoids (Suh et al., 2000; Goulart et al., 2008; Hegazi and Khafagi, 2001).

\section{Insecticide Persistence}

Mortality of the parasitoid after exposure to aged residues of the tested insecticides on tomato leaves differed among the insecticides and different age of residues (Table 4). Cypermethrin and phenthoate resulted in $100 \%$ mortality of adult females exposed to one day old residues and were classified as harmful (IOBC class 4) to T. cacoeciae. One day old residues of deltame-

Table 4. Mean \% survival of adult females of the egg parasitoid Trichogramma cacoeciae, when exposed to aged insecticide residues (persistence of insecticide effect).

\begin{tabular}{|c|c|c|c|c|c|c|c|}
\hline \multirow{3}{*}{ Insecticide } & \multirow{3}{*}{ Class } & \multicolumn{5}{|c|}{ Mean adult survival (\%) } & \multirow{3}{*}{$\begin{array}{l}\text { IOBC Classifi- } \\
\text { cation }\end{array}$} \\
\hline & & \multicolumn{5}{|c|}{ Days after treatment } & \\
\hline & & 1 & 2 & 3 & 7 & 14 & \\
\hline $\begin{array}{l}\text { Cypermethrin } \\
\text { (Hil power) }\end{array}$ & & $0.00 \mathrm{~d}$ & $5.00 \mathrm{~d}$ & $14.00 \mathrm{~d}$ & $31.00 \mathrm{e}$ & $39.00 \mathrm{de}$ & 4 \\
\hline $\begin{array}{l}\text { Deltamethrin } \\
\text { (Flotron 2.5\%) }\end{array}$ & Pyrethroid & $4.00 \mathrm{~cd}$ & $6.00 d$ & $16.00 \mathrm{~d}$ & 29.00 ef & $42.00 \mathrm{~d}$ & 3 \\
\hline $\begin{array}{l}\text { Malathion } \\
\text { (Sulmathion 57\%) }\end{array}$ & Organophos- & $2.00 \mathrm{~cd}$ & $9.00 \mathrm{~d}$ & $18.00 \mathrm{~d}$ & 26.00 ef & 34.00 ef & 3 \\
\hline $\begin{array}{l}\text { Phenthoate } \\
\text { (Peston 50\%) }\end{array}$ & phate & $0.00 \mathrm{~d}$ & $7.00 \mathrm{~d}$ & $15.00 \mathrm{~d}$ & $24.00 \mathrm{fg}$ & $24.00 \mathrm{~g}$ & 4 \\
\hline $\begin{array}{l}\text { Methomyl } \\
\text { (Metho900) }\end{array}$ & & $7.00 \mathrm{~cd}$ & $8.00 \mathrm{~d}$ & $13.00 \mathrm{~d}$ & $25.00 \mathrm{efg}$ & $31.00 \mathrm{fg}$ & 3 \\
\hline $\begin{array}{l}\text { Carbosulfan } \\
\text { (Marshal 25\%) }\end{array}$ & Carbamate & $7.00 \mathrm{~cd}$ & $12.00 \mathrm{a}$ & $15.00 \mathrm{~d}$ & $25.00 \mathrm{efg}$ & 36.00 def & 3 \\
\hline $\begin{array}{l}\text { Bistrifluron } \\
\text { (Hanaro 10\%) }\end{array}$ & & $1.00 \mathrm{~b}$ & $83.00 \mathrm{~b}$ & $84.00 \mathrm{~b}$ & $86.00 \mathrm{~b}$ & $94.00 \mathrm{a}$ & 1 \\
\hline $\begin{array}{l}\text { Pyriproxyfen } \\
\text { (Muligan 10\%) }\end{array}$ & IGR & $77.00 \mathrm{~b}$ & $77.00 \mathrm{~b}$ & $49.00 \mathrm{~b}$ & $80.00 \mathrm{c}$ & $85.00 \mathrm{~b}$ & 1 \\
\hline $\begin{array}{l}\text { Matrine } \\
\text { (Kingbo 0.6\%) }\end{array}$ & & $41.00 \mathrm{~d}$ & $45.00 \mathrm{c}$ & $47.00 \mathrm{c}$ & $49.00 \mathrm{~d}$ & $52.00 \mathrm{c}$ & 2 \\
\hline $\begin{array}{l}\text { Azadirachtin } \\
\text { (Amen 1.0\%) }\end{array}$ & Plant Extract & $9.00 \mathrm{c}$ & $10.00 \mathrm{~d}$ & $13.00 \mathrm{~d}$ & $19.00 \mathrm{~g}$ & $26.00 \mathrm{~g}$ & 3 \\
\hline Control & & $20 a$ & & & & & \\
\hline LSD $(P>0.05)$ & & 25.503 & 20.533 & 24.093 & 27.348 & 17.855 & \\
\hline F value & & 0.007 & 0.249 & 0.041 & 0.044 & 0.041 & \\
\hline
\end{tabular}

All values are means of 5 replicates. Means in the same column followed by the same letter are not significantly different (Fisher's test, $\mathrm{P}>0.05)$. IOBC insecticide classification where Class 1: harmless $(\mathrm{E}<30 \%)$; Class 2: slightly harmful $(30 \%<\mathrm{E}<79 \%)$; Class 3: moderately harmful $(80 \%<\mathrm{E}<99 \%)$; and Class 4: harmful $(\mathrm{E}>99 \%)$. 
thrin, malathion, methomyl, azadirachtin, and carbosulfan, causing 96, 98, 93, 91 and 93\% adult mortality, respectively, as compared with the control, are classified as moderately harmful (IOBC class 3 ) to T. cacoeciae. Our results corroborate those reported by Youssef et al. (2004) for T. exgium on olive leaves, and Blibech et al. (2015) who found that deltamethrin residues on olive leaves affected parasitism in T. oleae, T. cacoeciae, and T. bourarachae, 31 days post-treatment. Nevertheless, Suh et al. (2000) showed that deltamethrin has short-term persistence on cotton leaves, and this difference in persistence may be attributed to variation among Trichogramma spp. sensitivity to pesticides (Goulart et al., 2008) and pesticide interactions with plant leaf types or climate conditions (Bueno et al., 2008).

One day old residues of the IGR insecticides, bistrifluron and pyriproxyfen, caused $19 \%$ and $23 \%$ mortality of T. cacoeciae, respectively, and were classified as harmless. One and 14 days post-treatment residues of the botanical insecticide matrine caused $59 \%$ and $48 \%$ mortality, respectively, and were classified as slightly harmful. According to Brunner et al. (2001) the benzoylhydrazin IGRs, tebufenozid and methoxyfenozide, on treated Oregon spur apple tree leaves at leaf-disk bioassays produced no sublethal effect on Colpoclypeus florus (Hym.: Eulophidae) and Trichogramma platneri, which are potential biological control agents of leafrollers in apple orchards.

Overall, toxicity of insecticide residues on tomato leaves to T. cacoeciae, from one to 14 days after treatment varied among the insecticides (Table 4). However, most of them were considered moderately harmful to harmful $24 \mathrm{~h}$ post-treatment. Residue toxicity reduced with time and became moderately harmful, 2 and 3 days after treatment and slightly harmful at 7 and 14 days. Zhu et al. (2009) also noted that persistence of insecticide residues on leaf surfaces differed among pesticides and that the effects on the natural enemy $T$. evanescens in their study decreased with time. Also, the understudy IGR aged residues were harmless at all time points after -application and these results are consistent with those reported by Hassan et al. (1998).

In conclusion, most of the tested insecticides were moderately harmful to harmful to T. cacoeciae, except for the IGR insecticides, which can be considered further for use in a sustainable IPM programme against major Lepidopteran pests of date palm.

We thank the Deanship of Scientific Research for financial support and the Center for Date Palm Research at King Faisal University for support and technical assistance. We thank Dr Hisham Mohammed for statistical advice.

\section{Literature cited}

Abaar, F., Hajjar, M.J. and Jamal, M. 2011. The side-effects of some insecticides on the adults of egg parasitoid Trichogramma cacoeciae Marchal (Hym: Trichogrammatidae). Journal of Damascus University for Agricultural Sciences, 27(2): 275-263.

Abaar, F., Hajjar, M.J. and Jamal, M. 2010. The sideeffect of some insecticides on the life stages of egg parasitoid Trichogramma cacoeciae Marchal (Hym: Trichogrammatidae) within host eggs. Arab Journal of Plant Protection, 28 (1): 85-90.

Abbott, W.S. 1925. A method for computing the effectiveness an insecticide. Journal of Economic Entomology, 18: 265-267.

Abdelgader, H. and Hassan, S. 2012. Effects of Botanical Insecticides on the Egg Parasitoid Trichogramma cacoeciae MARCHAL (Trichogrammatidae: Hymenoptera). Third International Scientific Symposium "Agrosym Jahorina 2012" Pp: 445450, (Ed: Kovacevic, D.) ISBN 978-99955-751-0-6.

Abdulhay, H.S. and Rathi, M.H. 2014. Effect of some insecticides on the egg parasitoid, Trichogramma evanescens Westwood (Hymenoptera: Trichogrammatidae). Journal of Al-Nahrain University, 17: 116-123.

Beserra, E.B. and Parra, J.R.P. 2004. Biologia e parasitismo de Trichogramma atopovirilia Oatman \& Platner e Trichogramma pretiosum Riley (Hymenoptera: Trichogrammatidae) em ovos de Spodoptera frugiperda (J. E. Smith) (Lepidoptera, Noctuidae). Revista Brasileira de Entomologia, 48: 119-126.

Blibech I., Ksantini, M., Jardak, T. and Bouaziz, M. 2015. Effect of insecticides on Trichogramma parasitoids used in biological control against Prays oleae insect. Advances in Chemical Engineering and Science, 5: 362-372.

Brunner, J.F., Dunley, J.E., Doerr, M.D. and Beers, E.H. 
2001. Effect of pesticides on Colpoclypeus florus (Hymenoptera: Eulophidae) and Trichogramma platneri (Hymenoptera: Trichogrammatidae), Parasitoids of Leafrollers in Washington. Journal of Economic Entomology, 94: 1075-1084.

Bueno, A.F., Bueno, R.C.O.F., Parra, J.R.P. and Vieira, S.S. 2008. Effects of pesticides used in soybean crops to the egg parasitoid Trichogramma pretiosum. Ciência Rural, 38:1495-1503.

Consoli, F.L., Botelho, P.S.M. and Parra, J.R.P. 2001. Selectivity of insecticides to the egg parasitoid Trichogramma galloi Zucchi, (Hym., Trichogrammatidae). Journal of Applied Entomology, 125: 37-43.

Consoli, F.L., Parra, J.R. and Hassan, S.A. 1998. Sideeffects of insecticides used in tomato field on the egg parasitoid Trichogramma prestiosum Rily (Hym., Trichogrammatidae), a natural enemy of Tuta absoluta (Meyrick) (Lep., Gelechiidae). Journal of Applied Entomology, 122: 43-47.

Desneux, N., Decourtye, A. and Delpuech, J.M. 2007. The sublethal effects of pesticides on beneficial arthropods. Annual Review of Entomology, 52: 81-106.

El-Shafie, H., Abdel-Banat, B. and Al-Hajhoj, M.R. 2017. Arthropod pest of date palm and their management. CAB Reviews, 12:49. http://www. cabi.org/cabreviews

Firake, D.M. and Khan, M.A. 2010. Influence of some plant oils on the parasitization potential and adult emergence of Trichogramma chilonis Ishii and Trichogramma poliae Nagaraja. Journal of Insect Science, 23: 430-433.

Firake, D.M., Lytan, D., Behere, G.T. and Thakur, N.S.A. 2012. Host plants alter the reproductive behavior of cabbage butterfly, Pieris brassicae (Lepidoptera: Pieridae) and its endo-larval parasitoid, Hyposoter ebeninus (Hymenoptera: Ichneumonidae) in cruciferous ecosystems. Florida Entomologist, 95: 905-913.

Godfray, H.C.J. 1994. Parasitoids. Behavioral and Evolutionary Ecology. Princeton University Press, Princeton, N.J.

Goulart, R.M., De Bortoli, S.A., Thuler, R.T., Pratissoli, D., Viana, C.L.T.P. and Volpe, H.X.L. 2008. Evaluation of the selectivity of insecticides to in diferentes hospedeiros. Arquivos do Instituto Biológico, 75: 69-77.

Grutzmacher, A.D., Zimmermann, O., Yousef, A. and Hassan, S.A. 2004. The side-effects of pesticides used in integrated production of peaches in Brazil on the egg parasitoid Trichogramma cacoeciae Marchal (Hym., Trichogrammatidae). Journal of Applied Entomologist, 128: 377-383.

Hassan, S.A. 1993. The mass rearing and utilization of Trichogramma to control lepidopterous pests: achievements and outlook. Pest Management Science, 37: 387-391.

Hassan, S.A. 1998. The suitability of Trichogramma cacoeciae as an indicator species for testing the side effects of pesticides on beneficial arthropods, compared to other hymenopterous parasitoids. IOBC/WPRS Bulletin, 21: 89-92.

Hassan, S.A., Hafes, B., Degrande, P.E. and Herai, K. 1998. The side effects of pesticides on the egg parasitoid Trichogramma cacoeciae Marchal (Hym., Trichogrammatidae), acute dose-response and persistence tests. Journal of Applied Entomology, 122: 569-573.

Hassan S.A., Halsa, I.I.N., Gray, A.P., Kuehnerc, M.M., Bakker, F.M., Roembke, J., Yousef, A., Nasr. F. and Abdelgader, H.A. 2000. A laboratory method to evaluate the side effects of plant protection products on Trichogramma cacoeciae Marchal (Hym., Trichogrammatidae), pp. 107-119. In: Guidelines to evaluate side effects of plant protection products to non-target arthropods (eds. M.P. Candolfi, S. Blümel, R. Forster, F.M. Bakker, C. Grimm, S.A. Hassan). IOBC/WPRS, Reinheim, Germany. pp. 107-119.

Hegazi, E.M. and Khafagi, W.E. 2001. Pattern of egg management by Trichogramma cacoeciae and $T$. dendrolimi (Hymenoptera: Trichogrammatidae). Biocontrol Science and Technology, 11: 353-359.

IOBC Pesticide Side Effect Database. 2005. IOBC/ WPRS. https://www.iobc-wprs.org/ip_ipm/IOBC_ Pesticide_Side_Effect_Database.html. Accessed March 2016.

Jiu-Sheng, Z.H.U., Mei-Li, L.I.A.N., Jing, W.A.N.G. and Shu, Q.I.N. 2010. Toxicity and safety evaluation of five insecticides on egg parasitoid, Trichogramma evanescens Westwood. Chinese Journal of Eco-Agriculture, 17: 715-720.

Moezipour, M., Kafil, M. and Allahyari, H. 2008. Functional response of Trichogramma brassicae at different temperatures and relative humidities. Bulletin of Insectology, 61: 245-250.

Polaszek, A. 2010. Biodiversity and host associations of Trichogramma in Eurasia, pp. 237-266. In: F. L. Consoli, J.R P. Parra, R.A. Zucchi (eds.), Egg Parasitoids in Agroecosystems with Emphasis on Trichogramma. Springer, New York, NY.

Rubeai, H.F., Al-Maiky, S.K., Gahrbawi, Z.A. and Salman, A.H. 2003. Mass-rearing of egg parasitoid Trichogramma embryophagum Harttig (Hym: Trichogrammatidae). Iraqi Journal of Science, 44(1):10-26.

Schuld, M. and Schmuck, R. 2000. Effects of Thiacloprid, a new chloronicotinyl insecticide, on the egg parasitoid Trichogramma Cacaoeciae. Ecotoxicology, 9: 197-205.

Sohrabi, F. and Amini, E. 2015. Effect of pesticides used in tomato fields of Iran on the egg parasitoid Trichogramma brassicae (Hymenoptera: Trichogrammatidae) under laboratory conditions. Biological Forum - An International Journal, 7: 975-980.

SPSS Inc. 2003. SPSS Base 12.0 for Windows User's 
Guide. Chicago, IL: SPSS Inc., USA.

Steel, R.G.D., Torrie, J.H. and Dickey, D.A. 1997. Principles and procedures of statistics: a biometrical approach. McGraw Hill Inc., New York, NY.

Suh, C.P.C., Orr, D.B. and Duyn, J.W. 2000. Effect of insecticides on Trichogramma exiguum (Trichgrammatidae: Hymenoptera) preimaginal development and adult survival. Journal of Economic Entomology, 93: 577-583.

Thubru, D.P., Firake, D.M. and Behere, G.T. 2016. Assessing risks of pesticides targeting lepidopteran pests in cruciferous ecosystems to eggs parasitoid, Trichogramma brassicae (Bezdenko). Saudi Journal of Biological Sciences. https://doi. org/10.1016/j.sjbs.2016.04.007
Youssef, A.A., Nasr, F.N., Stefanos, S.S., Abou Elkhair, S.S., Shehata, W.A., Agamy, E., Herz, A. and Hassan, S.A. 2004. The side effects of plant protection products used in olive cultivation on the hymenopterous egg parasitoid Trichogramma cacoeciae Marchal. Journal of Applied Entomology, 128: 593-599.

Zhu, J., Mei-Li, L., Jing, W. and Shu, Q. 2009. Toxicity and safety evaluation of five insecticides on egg parasitoid, Trichogramma evanescens Westwood. Chinese Journal of Eco-Agriculture, 17: 715-720.

Received: 14 February 2018; Accepted: 18 June 2018

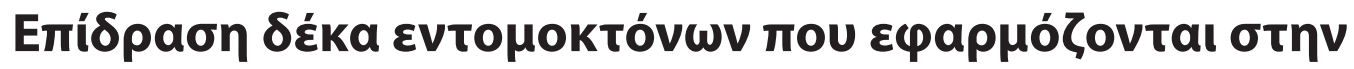

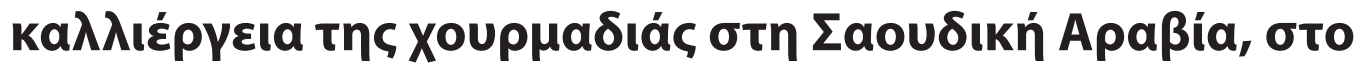

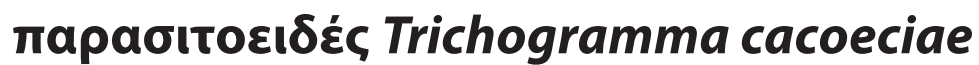

\section{Jamal Hajjar and M. Al-Masoud}

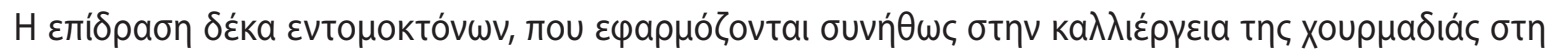

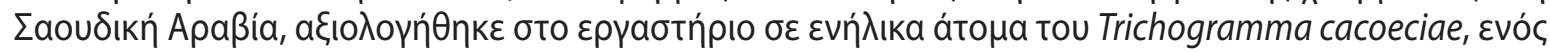

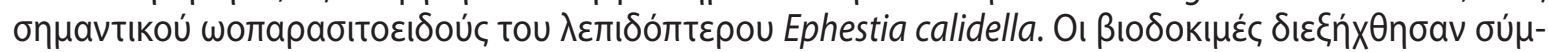

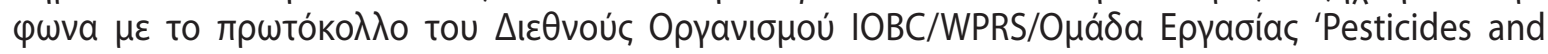

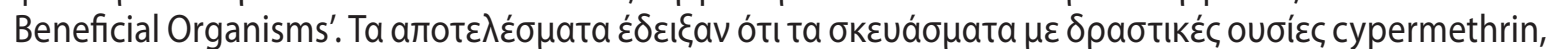

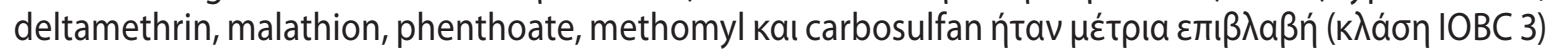

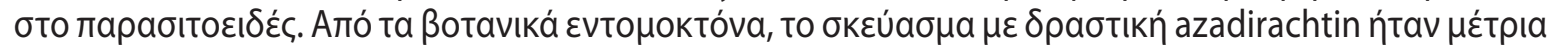

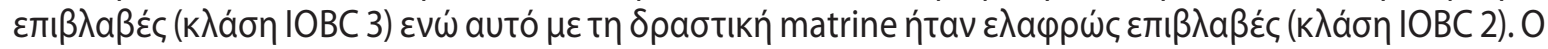

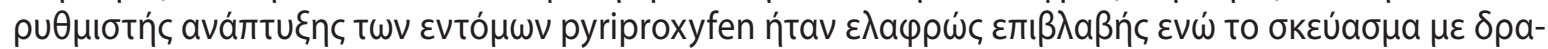

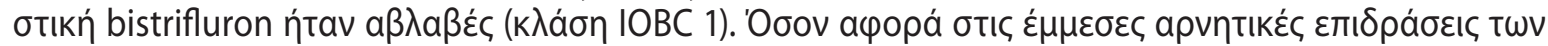

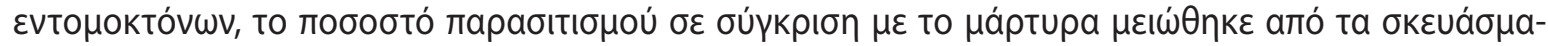

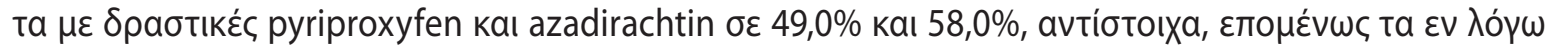

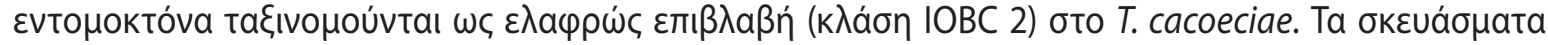

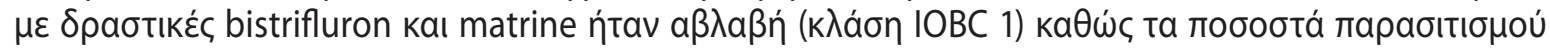

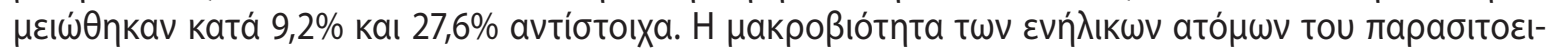

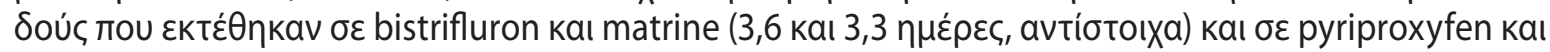

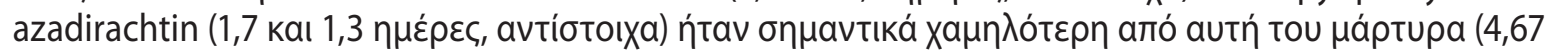

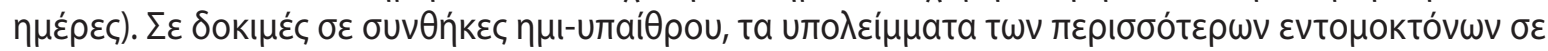

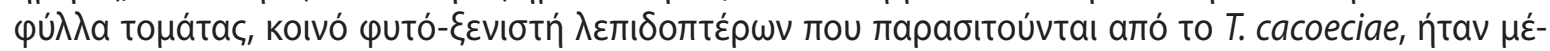

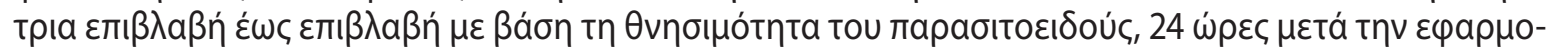

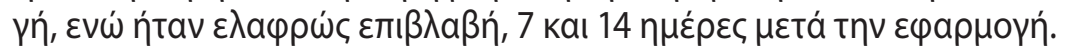

